\title{
Current Status of Islet Cell Transplantation
}

\author{
Hirohito Ichii ${ }^{\mathrm{a}, \mathrm{b}}$ and Camillo Ricordi ${ }^{\mathrm{a}, \mathrm{b}}$ \\ aCell Transplant Center, Diabetes Research Institute, University of Miami Leonard M. Miller \\ School of Medicine, Miami, FL, USA \\ ${ }^{b}$ DeWitt Family Department of Surgery, University of Miami Leonard M. Miller School of Medicine, \\ Miami, FL, USA
}

\begin{abstract}
Despite substantial advances in islet isolation methods and immunosuppressive protocol, pancreatic islet cell transplantation remains an experimental procedure currently limited to the most severe cases of type 1 diabetes mellitus (T1DM). The objectives of this treatment are to prevent severe hypoglycemic episodes in patients with hypoglycemia unawareness, and to achieve a more physiological metabolic control. Insulin independence and long term-graft function with improvement of quality of life have been obtained in several international islet transplant centers. However, experimental trials of islet transplantation clearly highlighted several obstacles that remain to be overcome before the procedure could be proposed to a much larger patient population. This review provides a brief historical perspective of islet transplantation, islet isolation techniques, the transplant procedure, immunosuppressive therapy, and outlines current challenges and future directions in clinical islet transplantation.
\end{abstract}

\section{INTRODUCTION}

Type 1 diabetes mellitus (T1DM) is an autoimmune disease associated with selected genetic HLA alleles, which results in the permanent destruction of beta cells of the pancreatic islets of Langerhans (1). In T1DM, the destruction of pancreatic beta cells causes insulinopenia, leading to consequent hyperglycemia and ketoacidosis unless the lack of endogenous insulin production is balanced by multiple exogenous insulin injections, which remain today the primary treatment for T1DM together with regular monitoring of blood glucose levels. While exogenous insulin therapy has dramatically improved the quality of life, chronic diabetic complications develop in a substantial proportion of subjects with diabetes and generally show a progressive worsening over time. Intensive insulin therapy has proven effective to delay and sometimes prevent the progression of complications such as nephropathy, neuropathy or retinopathy. However, it is difficult to achieve and maintain long term in most subjects, either for compliance issues or for the increased risk of severe hypoglycemic episodes, which is generally associated with intensification of exogenous insulin therapy. A more physiological glycemic control could be provided by pancreatic beta cells. Some of the most difficult cases of T1DM include patients who lost their ability to feel hypoglycemic prodromic symptoms such as sweating, tremor, tachycardia and anxiety. Since it is very challenging and potentially dangerous to treat these subjects with intensive insulin therapy, transplantation of insulin-producing cells could be of assistance in restoring proper glucose regulation.

\footnotetext{
*Address correspondence to: Hirohito Ichii, M.D, Ph.D., Cell Transplant Center, Diabetes Research Institute, University of Miami Leonard M. Miller School of Medicine, 1450 NW 10th Avenue (R-134), Miami, Florida 33136, Phone: (305) 243-3700, Fax: (305) 243-4404, hichii@med.miami.edu.
} 
Whole organ pancreas transplantation is very effective in restoring normoglycemia and maintaining long-term physiological glycemic control. Simultaneous pancreas and kidney transplantation is presently considered the standard therapy for patients with T1DM with end-stage renal failure. Although pancreas transplantation achieves insulin independence in greater than $80 \%$ of patients beyond 1 year (2), it retains the risks associated with any major surgical procedures and long-term immunosuppressive drug therapy (3). In contrast, islet transplantation does not require any significant surgery, or general anesthesia. In addition, islet transplants do not require management of the exocrine secretions of the pancreas, avoids the possible complications related to enzymes production by the exocrine cells, as experienced in whole organ, pancreas transplantation. In patients with TD1M, there is no significant problem with the pancreatic exocrine tissue, which represents the majority of the organ. It would make sense to limit the transplant procedure to the islets that represent less than $2 \%$ of the organ and that could easily be infused by interventional radiology techniques, either intraportally or in other sites.

The first report of an islet transplant as a treatment for diabetes could be considered that of Dr. Watson-Williams and Mr. Harshant in 1894, when they transplanted small fragments of a sheep pancreas into a young patient with diabetic ketoacidosis. However, no attempt to purify the islets was performed in that initial attempt. Since then, significant progress has been achieved in the field of islet transplantation (4). The first successful series of islet allografts was reported in 1990 in surgical diabetes(5), while the results in T1DM slowly improved during the 90s, until 1999, when Shapiro et al. reported insulin independence in seven out of seven consecutive T1DM patients treated with islet transplantation using a glucocorticoid-free immunosuppressive regimen (6). Since this exciting report, clinical islet transplantation activity has dramatically increased all over the world. A multi-center trial to evaluate the reproducibility of the Edmonton study, organized by the Immune Tolerance Network reported variable rates of success, indicating that the complexity of the procedure should not be underestimated by new center entering the field (7). In the centers with most experience with the procedure, approximately $80 \%$ of patients treated with islet transplantation could achieve insulin independence within the first year post-transplantation (7).

\section{Clinical Islet Transplantation}

\section{Indications}

The risk/benefit ration should be carefully evaluated in each patient where islet transplantation is considered, as adverse events are frequently observed following islet transplantation, mainly related to immunosuppressive therapy. Strict recipient evaluation is essential for selecting patients suitable for islet transplantation. The ideal candidates for islet cell transplantation are patients with unstable T1DM and have a history of severe hypoglycemia unawareness, despite attempts to correct the condition by expert medical treatment (8).

\section{Donor evaluation}

Donor selection has been strongly associated successful islet isolation and transplantation. It has been reported that significantly higher isolation outcomes were associated with several donor variables including donor age $(9,10)$, body mass index (11) and retrieval by the local surgical team $(12,13)$. In general, donor pancreata are first offered for whole pancreas transplantation. If donors have a high body mass index, the pancreata are not generally used for whole pancreas transplantation (14). However, pancreata from high BMI donors could be successfully used for islet transplantation, generally providing a higher islet yield compared to those from lean donors (10), (15). Middle-aged donors are considered most 
suitable for islet isolation (15). However, the superiority of young donor islet function has also been reported (16) (17). The major obstacle in the utilization of young donor pancreata is low islet yields (18) (19). This is due to the difficulty of separating islets in young donor pancreata from the surrounding acinar tissue without fragmenting the islets (15), (20).

Developing isolation methods to increase islet yields from young donor pancreata will be of assistance in improving the number of donors that could successfully be utilized for clinical islet transplantation. Besides low BMI and donor age, low islet yields have also been associated with uncontrolled hyperglycemia (21), prolonged hypotensive episodes, longer cold ischemia time (11), pancreas capsular damage (22), duration/frequency of donor cardiac arrest and the elevation of serum creatinine levels and transaminases vasopressors (11).

\section{Pancreas Preservation for islet transplantation}

In whole pancreas transplantation, pancreata have been preserved in University of Wisconsin solution (UW) $(23,24)$. Reducing pancreatic injury, particularly from cold ischemic injury, has been recognized to be increasingly more important for human islet isolation over the past several years. Kuroda et al. have first reported that the two-layer method, in which the pancreas is stored at the interface of UW solution and oxygenated PFC (perfluorochemical), is effective for pancreas preservation (25). Since then, the two-layer preservation method has been utilized for many clinical trials in islet transplantation (26-29).

\section{Digestion}

Islet isolation methods from human pancreas have significantly improved over the last three decades. The introduction of the semi-automated method for controlled pancreatic digestion using a dissociation chamber (Ricordi chamber) has dramatically increased islet yields from human pancreata (30) and the general principles of this method are still at the base of current islet isolation technology $(4,31-33)$. This procedure includes islet separation from the exocrine pancreatic tissue in a digestion chamber (Ricordi Chamber) by a mechanicallyenhanced continuous enzymatic digestion process. The progressively digested pancreatic tissue is effectively collected with a large volume of solution. In a following purification procedure, the islets are separated from the acinar tissue using discontinuous or continuous density gradient centrifugation (33)(34-36).

\section{Enzyme}

The enzymatic dissociation of islet cells from the surrounding exocrine tissue plays an important role in the achievement of a successful human islet isolation and clinical transplantation $(18,37)$. Liberase, a highly purified, low endotoxin, enzyme blend composed of a consistent combination of collagenase class I and II, as well as the neutral protease thermolysin, was developed by Roche Applied Science $(36,38,39)$. Highly purified Liberase $\mathrm{HI}$ has dramatically improved the consistency, yield and function of islets by minimizing the variables of quality and stability when compared to the conventional crude collagenases. Liberase $\mathrm{HI}$ is currently the primary choice and the best-characterized enzyme blend throughout the field of human islet isolation. However, significant variability in enzymatic activity between lots has been reported (40-42). Additionally, there is lot specific deterioration of enzyme quality and strength over time (43). Therefore, several test isolations have been necessary for the selection of Liberase lots suitable for human islet isolation based on islet yield and quality. The deterioration of the enzymatic quality may be caused by the degradation of neutral protease activity in Liberase HI during storage, even if the enzymes are stored at $-80^{\circ} \mathrm{C}$ according to manufacturer's instructions (41).

One solution to this problem would be to obtain smaller batches of enzyme and utilize them in shorter time periods. However, experience dictates a substantial number of pancreata are 
utilized in order to select suitable Liberase lots, and optimize isolation conditions to obtain a consistently high yield and quality of islets. In order to avoid the increased waste of pancreata and time, it would be useful to establish a network system of sharing Liberase lots and isolation conditions for each suitable lot among islet processing centers. It has been published that precise enzyme characterization would be helpful for selecting enzyme lots suitable for islet isolation and evaluating degradation of enzyme over time $(37,44)$. In addition, it might also be advantageous to utilize a 'non-blend' component enzyme; Liberase Collagenase Blend (Roche Applied Science), Collagenase NB1 and Neutral Protease NB (Serva Electrophoresis $\mathrm{GmbH}$ ), which would separate the class I and class II collagenases from the neutral proteases, in order to extend the shelf-life of the enzyme. Therefore, the separate enzyme components make it possible to prepare the suitable ratio for the conditions and the characteristics of donor pancreata $(37,45)$. In order to minimize the lot-to-lot variability of the activity of each enzyme component, a recombinant enzyme was developed and successfully tested for human islet isolation $(39,41)$. Recombinant technology could represent a significant advancement for better definition and reproducibility of successful enzyme blends for human islet processing.

\section{Purification}

The purification step allows for the separation of the islets, which represent only $1-2 \%$ of the total pancreatic tissue, and multiple fractions of variable degrees of islet purity are usually recovered (46). This procedure reduces the volume of tissue that will be implanted in the patient, therefore minimizing the risks associated with intraportal islet infusion (i.e., increase of portal pressure and thorombosis). The original description of the automated method for human islet isolation included density gradient centrifugatiousing a manual method (30). The semi-automated computerized COBE-2991 cell processor subsequently became the most effective method for the purification of human islets, as it allows large volumes of pancreatic digest to be purified in reasonably a short time $(34,35,46)$. Large-scale continuous purification using the COBE2991 cell processor, with top loading, is the current gold standard method(31-33, 47, 48). An important advantage of continuous gradient purification is that it allows collecting serial fractions with different degrees of purity that can be assessed separately in order to select those with the highest purity for transplantation. In addition, top-loading has the potential advantages of allowing the digested tissue to remain in a physiological medium for the maximum possible time and minimizes centrifugal forces.

Recently, we have reported an additional gradient purification method following continuous gradient purification with bottom loading could be of assistance in maximizing the number of islet preparations successfully used for transplantation by improving the efficiency in the purification of trapped islets, which often come from younger donor pancreata (49). In addition, Ficoll based gradient that were widely used (30) (5); (34); (35); have been progressively been replaced by Iodixanol-based gradients (50) (29) (33).

\section{Pre-transplant Culture}

Optimal culture conditions for isolated human islets should provide sufficient oxygen and nutrients, in order to allow islet cells to recover from isolation-induced damage and maintain the 3-dimensional structure of the clusters and reduce islet mass loss. Numerous approaches have been utilized over the years for the culture of human islets prior to transplantation. Initial clinical trials used islets cultured prior to transplantation in order to allow for the assessment of sterility and to allow for pooling of islet preparations from multiple donors, if needed, to obtain a sufficient number of islet for transplantation $(5,51-54)$. The Edmonton protocol required freshly-isolated islets to be transplanted without keeping them in culture (6). More recently, most transplant centers are culturing isolated human islet preparations, 
pre-transplantation, with results comparable to that of non-cultured $(18,29,32,47,48$, 55-57). The advantages of the using cultured islet preparations over freshly isolated islets are multifold and include practicality, as it allows for arranging the logistics of patient admission to the hospital and of implementing pre-conditioning therapy prior to transplantation; and safety, as it gives time to assess the islet preparation by performing microbiological (i.e., mycoplasma, aerobes and anaerobs cultures) and pyrogenic (endotoxin) tests. In addition, islet culture allows minimizing the risk of primary non function of the transplanted insulin producing cells, as it has been occasionally observed when islets were transplanted before appropriate functional tests could be performed.

Numerous media formulations and culture protocols have been utilized for human islets since the 1970's $(58,59)$. The current practice for islet culture varies substantially between centers, suggesting that despite the steady success reported in the clinical setting of islet transplantation in recent years, standardization has not been achieved. There is still a wide lattitude for the improvement of current methods utilized for the human islet cell culture. Development of efficient culture media formulations and of protocols specific to human islet preparations may allow improved preservation of $\beta$-cell mass and quality, while increasing the success rate of islet transplantation in the clinical setting.

The process of human islet isolation generates sizable stress to the islets, including the induction of apoptosis and necrosis and the production of pro-inflammatory cytokines and chemokines (60-62). In particular, oxidative stress appears to play a major role in triggering islet cell death during isolation (61). The activation of nuclear factor-KB (NF-KB) and PARP, two of the major pathways responsible for cellular responses to stress, are shown to be upregulated significantly in pancreatic cells during the isolation procedure (61). Furthermore, it has been recently reported that islets express and synthesize tissue factor (TF), which triggers a detrimental thrombotic reaction after hepatic portal islet infusion (63-65). Other reports have shown that macrophage chemoattractant protein-1 (MCP-1) is also expressed and secreted by islets (66-69). MCP-1 has a potent chemotactic activity for monocytes and MCP-1 levels inversely correlate with the outcome of clinical islet transplantation (68). Nicotinamide supplementation of culture medium has been shown to reduce both TF and MCP-1 production (70). Based on these premises, nicotinamide supplementation is currently used in the culture media of human islet preparations for clinical use $(32,65)$.

After isolation, most of islet cells will be hypoxic and have substantial damage. The cell density of islet preparations during culture plays an important role in islet survival. Oxygen diffusion in the media will be critical for islet survival during culture. Typical flask loading is equivalent to 115 to $133 \mathrm{IEQ} / \mathrm{cm}^{2}$ of surface area. Given a uniform islet size of $150 \mu \mathrm{m}$ diameter (15), this translates to a 1.2-2.4\% flask surface utilization. When the cell density exceeds the above cutoff, cells begin to experience anoxia and cell death in the core regions. When the cell number is increased, the anoxic tissue fraction increases precipitously to about $65 \%$ at a seeding density of approximately $500 \mathrm{IEQ} / \mathrm{cm}^{2}$.

Human islet preparations are cultured in humidified incubators $\left(95 \%\right.$ air, $\left.5 \% \mathrm{CO}_{2}\right)$. There is no consensus regarding the standardization of incubating temperature for human islet preparation culture. At the University of Miami, islet cell fractions, with a purity greater than $70 \%$, are cultured at $37^{\circ} \mathrm{C}$ for the first 24 hours and transferred to $22^{\circ} \mathrm{C}$ for the remaining 24-48 hours until transplantation $(32,49,65)$. Islet cell fractions with purity less than $70 \%$ are immediately cultured at $22^{\circ} \mathrm{C}$. Culture at $37^{\circ} \mathrm{C}$ for the first 24 hours may be helpful for the recovery of islet cells damaged during the isolation. Culturing islet preparations at $22^{\circ} \mathrm{C}$ until transplantation might favor reduction of exocrine cells, therefore improving the purity of the final preparations for transplantation. Improved islet culture 
conditions could also be a component of the recently reported improved rates of insulin independence with islets from a single donor $(29,33)$.

\section{Shipping human islets between centers}

The development of methods of culturing islet preparations for 48-72 hours prior to transplantation has also allowed shipping isolated islets to remote centers where islet transplantation is performed $(55,71-73)$. The need to ship islets between distant centers requires optimization of shipping conditions that allow maximizing preservation of islet mass, viability, potency and sterility. This will be of assistance in obtaining favorable outcomes in clinical islet transplantation trials, but also will improve distribution of human islet preparations to researchers at distant institutions without altering islet cell quality and physiology. In the GRAGIL (Group Rhin-Rhone-Alpes-Geneve pour la Transplantation d'Ilots de Langerhans) experience, islets are transported by an ambulance to the remote transplant centers where they are transplanted within a few hours loaded in a syringe or infusion bag utilized for islet implantation $(72,73)$. The University of California Islet Transplant Consortium reported shipping islets in the infusion bag to the remote centers within hours of isolation or after culture or cryopreserved prior to shipment $(74,75)$. Although the Minneapolis-Seattle collaboration reported the shipment of islet preparations for clinical trial, the detailed protocol for shipment is not available (76).

Partnerships between islet cell processing facility and distant islet transplant programs, where islets are shipped for transplant, are extremely beneficial $(55,71)$. To comply with FDA regulations, islet cell products are assessed before (at the islet cell processing facility) and after (at the remote islet transplant programs) shipment to confirm adequate quality (i.e., viability and sterility) and mass of islets are available for transplantation $(71,77)$. In the recently published series of islet transplants performed using the new consortium concept, islets were isolated from pancreata procured at the remote center, the Methodist Hospital at the Baylor's College of Medicine in Houston (78). Isolated islets were shipped to the remote partner, islet transplant programs, where product release and quality control were repeated before islets transplantation into patients with Type 1 Diabetes $(71,79)$. The results of the clinical trials reported to date are quite comparable to that of islets isolated and transplanted at the same center. Improved way to culture islets could include the recently developed oxygen sandwich technique (80). This technique allows for improved oxygen diffusion from a silicone-perfluorocarbon membrane positioned at the bottom of a specially made Petri-like raised dish. Moreover, the recently described vessels for islet shipment, developed by Papas and collaborators (81), also has a silicon membrane at the bottom of the container, which could allowing for more efficient oxygen diffusion to the islets while providing increased volumes of culture media during shipment.

\section{Islet Potency Tests}

While selected centers have reported high rates of success $(4,6,32,33,48,56,57,77,82)$, islet graft failures in the very early post-transplant period have been reported. These failures could be due to the use of islet preparations of less than optimal quality $(7,83)$. This problem may have been related to the lack of reliable assessment method $f$ islet quality prior to transplantation. Currently accepted product release criteria include viability measured by DNA-binding dye exclusion (84), islet cell purity based on dithizone (DTZ) staining (85, 86), and in vitro glucose-stimulated insulin release (86). According to these pre-transplant criteria, it is very difficult to distinguish islet preparations that could not reverse diabetes from those that resulted in good function. DNA-binding dye exclusion can only discriminate dead cells that have lost membrane permeability. In addition, this method cannot identify apoptotic cells or determine whether dead cells preferentially belong to any given subset. While dithizone staining can provide an estimate of endocrine cell content in islet 
preparations, it does not evaluate the beta cell content (86). The transplantation of islets to chemically induced diabetic immunodeficient mice can provide more predictive value based on the reversal of diabetes $(30,86)$. However, several days are required for the evaluation of islet quality, making it an unpractical pre-transplant product release criteria. We have recently reported that a method of analysis to objectively quantify cellular composition and fractional beta cell viability in human islet preparations, based on the use of Laser Scanning Cytometry (LSC) and and cytofluorimetry. Analysis of human islet preparations with these techniques allows for the definition of beta cell mass and viability. The assessment of beta cell specific apoptosis in combination with beta-cell mass in human islet preparations would theoretically provide a higher level of prediction than the currently used methods.

Experimental studies in diabetic immunodeficient mice have shown the ability to predict human islet cell potency in vivo (87). In clinical settings, this method has provided useful information in the prediction of islet graft function. As a different approach, measurements of the metabolic status of islets from the assessment of oxygen consumption rates (88-90) and the ATP/ADP ratio (91) have been proposed, which would be able to provide additional information in terms of islet quality. Therefore, a combined evaluation of islets from various standpoints such as the metabolic state, viability and function may be of assistance in providing useful product release criteria for the prediction of islet graft function.

\section{Transplant procedures}

Islet preparations are implanted into the recipient liver through the portal vein with a percutaneous transhepatic cannulation under sonographic and fluoroscopic guidance (92). Once access has been obtained, islets are slowly insfused using a closed bag system(93). Portal venous pressure, is measured by an indirect pressure transducer. After completion of the infusion the entry tract is plugged with a haemostatic sealant(94). The potential complications $(95,96)$ of an infusion into the liver include bleeding, portal vein thrombosis and portal hypertension The morbidity and mortality related to this procedure has been very low (97). Most patients require only a short hospital stay of 1-2 days. Since the success of the Edmonton protocol, heparin has added in order to reduce the clotting process, termed the instant blood mediated inflammatory reaction (IBMIR), occurring in the islet infusionsite $(63,64)$. The use of heparin might improve the survival of the rate islet graft $(98,99)$. In addition, the use of heparin and anti-coagulative profilaxis not just during the transplant procedure, but also for several days following islet transplantation, together with intensive insulin treatment for the first weeks post-transplant have been recently reported as potentially critically important variable to improve the efficiency of initial post-transplant engraftment and early survival of insulin producing cells.

\section{Immunosuppression}

Since the Edmonton group reported dramatically improved clinical outcomes using a steroid-free immunosuppressive protocol with a combination of sirolimus and tacrolimus, this protocol has been utilized in many clinical islet transplant trials. The adverse effects of sirolimus and tacrolimus include painful oral ulceration, diarrhea, constipation, peripheral edema, proteinuria, anemia, neutropenia, hypertension and hypercholesterolaemia (100). Although most patients tolerate the protocol well, some may require conversion to mycophenolate mofetil (MMF) because of the side effects (101). Although several studies have investigated the effects of sirolimus on $\beta$-cells in vivo or in vitro, the conclusions have often been conflicting $(33,102-106)$. Alternatively, Hering et al. has reported the success of their single donor islet infusion protocols using hOKT3 $y 1$ (Ala-Ala) $(29,33)$. The use of Rabbit anti-T-cell globulin (thymoglobulin), an anti-CD52 T cell- depleting antibody (alemtuzumab; Campath-1H) or CD20 rituximab (Rituxan) may be another potent therapy to improve islet transplantation outcomes $(107,108)$. 


\section{Clinical outcomes of islet transplantation}

Following the success of the Edmonton steroid-free immunosuppression protocol, multicenter trials organized by Immune Tolerance Netwok have been performed to evaluate the reproducibility of the Edmonton protocol. A $90 \%$ insulin-free rate was reported in three centers including us (Edmonton and Minneapolis), while the overall insulin independence rate was $52 \%$. Most type I diabetes recipients have significant benefits including improvements in glycemic control with normalization of $\mathrm{HbA} 1 \mathrm{c}$ and substantial reduction of exogenous insulin requirements $(6,29,31-33,47,57,72,109-111)$. Insulin independence is achieved by transplanting a sufficient number of islet mass (approximately $10,000 \mathrm{IEQ} / \mathrm{kg}$ of recipient's body weight) $(33,48,112)$, Therefore, more than one donor pancreas per recipient are necessary for achieving insulin independence $(29,33,111,112)$. A major problem in current islet transplantation is a progressive loss of insulin independence over time. However, recent reports from Edmonton suggest that 83\% of patients show islet function assessed by C-peptide secretion at 5 years (33). Furthermore, hypoglycemia was prevented even when exogenous insulin was required to maintain glycemic control (33, 111-113), and the HbA1c level was well controlled in those back on insulin but C-peptide positive. The effects on the prevention of hypoglycemia can persist as long as residual islet function is retained $(77,114)$.

In a recent report of the comparison between renal transplant recipients who had islet transplantation or whole pancreas transplantation, there was no significant difference in diabetic control at 3 years between the groups, even though many islet recipients returned to need exogenous insulin therapy (112). There are several reasons for the progressive loss of transplanted beta cells over time, which include chronic allograft rejection, beta cell toxicity from immunosuppressive drugs, recurrence of autoimmunity, and immunosuppressionrelated loss of beta cell regenerative capacity.

The effect of allosensitization on islet graft function in islet allotransplantation requires further investigation. Allosensitization in patients receiving islet grafts was not oftenoften observed as long as they werewere taking immunosuppressive medication (115-117). However, the negative effects of allosensitization on islet trasplnat recipientsrecipients should be precisely evaluated in the near future.

\section{Present challenges and future directions in clinical islet transplantation}

\section{Single donor islet transplantation}

Under the current human islet transplantation protocols, a successful islet transplantation is achieved with islets generally obtained from multiple donors $(6,7,32,48)$. It is still difficult to consistently obtain islet yields that meet the minimal requirements of $10,000 \mathrm{IEQ} / \mathrm{kg}$ of recipient weight for insulin independence. Hering et al. reported successful islet transplantation outcomes using islets isolated from a single donor (33). In his protocol, all eight recipients achieved insulin independence, and five of these patients remained insulin free for more than 1 year. In order to achieve a donor:recipient ratio of 1:1 in clinical islet transplantation, major efforts are currently being focused toward the standardization of islet cell processing among centers, including those participating in the NIH funded Clinical Islet Transplant (CIT) consortium, which is currently involved in the first 2 Phase III trials of islet transplantation (http://www.citisletstudy.org/resources.html).

\section{Living donor islet transplantation}

Living donor islet transplantation could be an alternative approach to expand the potential donor pool. The first successful islet transplantation from living donor was reported by Matsumoto et al in Kyoto, Japan (33). Unpurified islet preparations isolated from the distal 
pancreas form a mother were transplanted to the recipient suffering from chronic pancreatitis. The recipient became insulin independent for more than one year. The donor had stable glucose homoeostasis post-donation. Although there are significant advantages in living donor islet transplantation, this should be considered only after a thorough evaluation of donor risks. Living donor islet transplantation may be possibly considered when the progressive islet graft dysfunction over time is overcome with safer and more efficacious interventions.

\section{Regional center}

Transferring the knowledge and expertise required for acquiring sufficient numbers and quality of islet preparations has proven to be a difficult challenge for newly established islet cell processing centers. The need for specific infrastructures, dedicated personnel and the acquisition of specialized expertise in islet cell processing has substantial economical impact and requires a long-term commitment to starting an islet transplant program $(48,77)$. This is intrinsic of the technology involved for human islet cell isolation and culture. Recent clinical multi-center trials have highlighted the critical role of center's experience in the success rate of the clinical islet transplant program $(7,118)$. This observation, together with the burden of demanding regulations for the production of clinical cell products for transplantation, have stimulated an increased interest for the implementation of regional islet cell processing centers to isolate high quality human islet cells for transplantation at remote centers. This approach has proven successful in recent clinical trials to maximize the success rate of islet isolation while containing the costs of establishing a fully operational cGMP facility. This strategy has allowed the performance of successful clinical trials both in United States and Europe with excellent outcomes $(55,71-76,119)$.

\section{Xenotransplantation}

Xenogeneic islets obtained from porcine pancreata are considered one of alternative sources for islet transplantation (120-123). Significant advances in the generation of genetically engineered porcine strains have been made. The engineered islets are free of the major xenoantigen $\alpha$-galactosyl. Islets isolated from such pigs show decreased anti-genicity and increased survival in non-human primate models of islet transplantation(124)(125). However, there are several obstacles to overcome, such as further reduction of antigenicity and the potential infection with pig endogenous retroviruses. (123). In order to solve these limitations, immunoisolation strategies such as encapsulation technology have been proposed to prolong islet graft survival (126-129). Hering et al. and Larcen et al. recently reported that transplanted porcine islets could restore glucose control more than 100 days in non-human primate models with a strong immunosuppressive protocol including costimulation blockade regimen. These results indicate that porcine islet xenotransplantation may be an alternative strategy in islet replacement therapy in the treatment of Type 1 diabetes $(130,131)$.

\section{Insulin-secreting cells}

Great progress has been made in recent years to differentiate beta cells from a wide variety of embryonic or adult stem cell subsets. Insulin-secreting cells have been obtained in vitro from diverse sources, including embryonic stem cells $(132,133)$. Several studies suggest that somatic stem cells can give rise to insulin-producing cells, including hepatic oval cells (134), splenic-derived cells (135) and marrow-derived cells (136). The differentiation potential of amniotic-derived stem cells is also appealing to this aim (137). Pancreatic ductal cells are closely associated with $\beta$-cells in the human pancreas (138) and have been shown to give rise to endocrine islet cells in both rodents and humans (139-141). Nevertheless, the recent result of treatment of diabetes in experimental model systems with human embryonic stem cell derived cell products represents an unprecedented result that underlies the 
importance of human embryonic stem cell research to provide a potentially unlimited source of insulin producing cells (142) (143).

\section{New immunosuppression}

Since loss of islet graft function over time was reported, modifications of immunosuppression protocol have been a key to improve long-term islet graft function. Several $\mathrm{T}$ cell depleting agents have been tested and have shown promising results. In the single-donor islet transplantation protocol in Minnesota (29), anti-CD3 mAb [hOKT3 $\gamma 1$ (Ala- Ala)] contributed to these promising results. A combination of anti-thymocyte globulin and rituximab (anti-CD20) has promoted long-term islet allograft survival in primates(108). Alemtuzumab (Campath-1H; anti-CD52 mAb) has been proven to be effective as an induction agent for renal transplantation (144-146).

Alternatively, peripheral tolerance has been proposed by co-stimulatory blockade of the CD80/86-CD28/CTLA4 pathway or the anti-CD40L antibodies in islet transplantation (147, 148). Although experimental tolerance induction has been tantalizing in animal transplant studies, significant challenges remain for clinical translation.

As a new co-stimulatory signal blocker, LEA29Y, which can block the interaction between CD28 and CD80, 86 on T cells, has shown promising data in primate trials (149). In renal transplantation, it has shown reduced chronic allograft nephropathy in patients treated with LEA29Y (150). In islet transplantation, clinical trials of LEA29Y are currently underway.

The induction immunological tolerance has been highly desirable in islet transplantation as well as in solid organ transplants. Kawai et al. have recently reported simultaneous kidney and bone marrow transplantation from five HLA single-haplotype mismatched living related donors into recipients. In this protocol, four out of five patients no longer require chronic immunosuppressive medications (151).

\section{Alternative sites}

In current clinical islet transplantation, islet grafts are transplanted into the recipient's liver. Islet grafts may be exposed to multiple stress including environmental toxins, particularly medications, absorbed from the gastrointestinal tract. Alternative sites more suitable for islet graft survival have been investigated in recent years. The omentum seems to be a more adventageous site for islet grafts since it is well vascularized and portally drained (152-155). A subcutaneous site including intramuscule may be altenative sites. The intramuscular autotransplantation of islets in a 7 year old child has recently been reported(156). Islet transplantation to subcutaneous sites using implantable devices has also shown promissing outcomes in animal moodels and will be tested in clinical trials in the near future (157-161).

\section{Conclusions}

Significant progress in beta-cell replacement therapies has occurred during recent years, with a progressive improvement of short-term and long term outcomes, including insulin independence, glycemic control with normalization of $\mathrm{HbA} 1 \mathrm{c}$ levels, prevention of severe hypoglycemic episodes and improvements of the quality of life in recipients with T1DM and hypoglycemic unawareness. The most recent results indicate that islet transplant recipients can maintained islet graft function without deterioration beyond 5 years progressively closing the gap with the results of whole organ, pancreas transplantation. Clinical trials using new pharmacotherapies and intervention therapies are ongoing and novel strategies are currently planned in this not so rapidly progressing, but consistently improving field. 


\section{Acknowledgments}

The authors are grateful to the members of the Human Cell Processing Facility, Preclinical Cell Processing Laboratory of the Cell Transplant Center, Clinical Islet Transplant Program, General Clinical Research Center, Imaging Core at the Diabetes Research Institute, Administrative Offices at the Diabetes Research Institute, and Organ Procurement Organizations for the continuous enthusiasm and support to our program. This work was supported in part by NIH-NCRR, GCRC MO1RR16587, NIDDK RO1-DK55347-IU42RR016603, 5R01 DK25802, ICR 5U42RR016603, JDRFI 4-200-946 and 4-2004-361, and the Diabetes Research Institute Foundation.

\section{References}

1. Larsen CE, Alper CA. The genetics of HLA-associated disease. Curr Opin Immunol. 2004; 16(5): 660. [PubMed: 15342014]

2. Sutherland DE, Gruessner RW, Gruessner AC. Pancreas transplantation for treatment of diabetes mellitus. World J Surg. 2001; 25(4):487. [PubMed: 11344403]

3. Stratta RJ. Late acute rejection episodes after vascularized pancreas transplantation. Transplant Proc. 1998; 30(4):1560. [PubMed: 9636633]

4. Ricordi C, Strom TB. Clinical islet transplantation: advances and immunological challenges. Nat Rev Immunol. 2004; 4(4):259. [PubMed: 15057784]

5. Tzakis AG, Ricordi C, Alejandro R, et al. Pancreatic islet transplantation after upper abdominal exenteration and liver replacement. Lancet. 1990; 336(8712):402. [PubMed: 1974944]

6. Shapiro AM, Lakey JR, Ryan EA, et al. Islet transplantation in seven patients with type 1 diabetes mellitus using a glucocorticoid-free immunosuppressive regimen. N Engl J Med. 2000; 343(4):230. [PubMed: 10911004]

7. Shapiro AM, Ricordi C, Hering B. Edmonton's islet success has indeed been replicated elsewhere. Lancet. 2003; 362(9391):1242. [PubMed: 14568760]

8. Ryan EA, Shandro T, Green K, et al. Assessment of the severity of hypoglycemia and glycemic lability in type 1 diabetic subjects undergoing islet transplantation. Diabetes. 2004; 53(4):955. [PubMed: 15047610]

9. O'Gorman D, Kin T, Murdoch T, et al. The standardization of pancreatic donors for islet isolation. Transplant Proc. 2005; 37(2):1309. [PubMed: 15848705]

10. Zeng Y, Torre MA, Karrison T, Thistlethwaite JR. The correlation between donor characteristics and the success of human islet isolation. Transplantation. 1994; 57(6):954. [PubMed: 7512294]

11. Brandhorst H, Brandhorst D, Hering BJ, Federlin K, Bretzel RG. Body mass index of pancreatic donors: a decisive factor for human islet isolation. Exp Clin Endocrinol Diabetes. 1995; 103(Suppl 2):23. [PubMed: 8839248]

12. Lakey JR, Warnock GL, Rajotte RV, et al. Variables in organ donors that affect the recovery of human islets of Langerhans. Transplantation. 1996; 61(7):1047. [PubMed: 8623183]

13. Ponte GM, Pileggi A, Messinger S, et al. Toward maximizing the success rates of human islet isolation: influence of donor and isolation factors. Cell Transplant. 2007; 16(6):595. [PubMed: 17912951]

14. Ris F, Toso C, Veith FU, Majno P, Morel P, Oberholzer J. Are criteria for islet and pancreas donors sufficiently different to minimize competition? Am J Transplant. 2004; 4(5):763. [PubMed: 15084172]

15. Ricordi C. Quantitative and qualitative standards for islet isolation assessment in humans and large mammals. Pancreas. 1991; 6(2):242. [PubMed: 1679542]

16. Ihm SH, Matsumoto I, Sawada T, et al. Effect of donor age on function of isolated human islets. Diabetes. 2006; 55(5):1361. [PubMed: 16644693]

17. Balamurugan AN, Chang Y, Bertera S, et al. Suitability of human juvenile pancreatic islets for clinical use. Diabetologia. 2006; 49(8):1845. [PubMed: 16783471]

18. Nano R, Clissi B, Melzi R, et al. Islet isolation for allotransplantation: variables associated with successful islet yield and graft function. Diabetologia. 2005; 48(5):906. [PubMed: 15830183]

19. Toso C, Oberholzer J, Ris F, et al. Factors affecting human islet of Langerhans isolation yields. Transplant Proc. 2002; 34(3):826. [PubMed: 12034198] 
20. Alderson D, Kneteman NM, Scharp DW. The isolation of purified human islets of Langerhans. Transplant Proc. 1987; 19(1 Pt 2):916. [PubMed: 3152636]

21. Powner DJ. Donor care before pancreatic tissue transplantation. Prog Transplant. 2005; 15(2):129. [PubMed: 16013461]

22. Sakuma Y, Ricordi C, Miki A, et al. Factors that affect human islet isolation. Transplant Proc. 2008; 40(2):343. [PubMed: 18374062]

23. D'Alessandro AM, Stratta RJ, Sollinger HW, Kalayoglu M, Pirsch JD, Belzer FO. Use of UW solution in pancreas transplantation. Diabetes. 1989; 38(Suppl 1):7. [PubMed: 2463200]

24. Munn SR, Kaufman DB, Field MJ, Viste AB, Sutherland DE. Cold-storage preservation of the canine and rat pancreas prior to islet isolation. Transplantation. 1989; 47(1):28. [PubMed: 2492130]

25. Kuroda Y, Kawamura T, Suzuki Y, Fujiwara H, Yamamoto K, Saitoh Y. A new, simple method for cold storage of the pancreas using perfluorochemical. Transplantation. 1988; 46(3):457. [PubMed: 3047936]

26. Matsumoto S, Qualley SA, Goel S, et al. Effect of the two-layer (University of Wisconsin solutionperfluorochemical plus O2) method of pancreas preservation on human islet isolation, as assessed by the Edmonton Isolation Protocol. Transplantation. 2002; 74(10):1414. [PubMed: 12451242]

27. Tsujimura T, Kuroda Y, Kin T, et al. Human islet transplantation from pancreases with prolonged cold ischemia using additional preservation by the two-layer (UW solution/perfluorochemical) cold-storage method. Transplantation. 2002; 74(12):1687. [PubMed: 12499881]

28. Ricordi C, Fraker C, Szust J, et al. Improved human islet isolation outcome from marginal donors following addition of oxygenated perfluorocarbon to the cold-storage solution. Transplantation. 2003; 75(9):1524. [PubMed: 12792508]

29. Hering BJ, Kandaswamy R, Harmon JV, et al. Transplantation of cultured islets from two-layer preserved pancreases in type 1 diabetes with anti-CD3 antibody. Am J Transplant. 2004; 4(3):390. [PubMed: 14961992]

30. Ricordi C, Lacy PE, Finke EH, Olack BJ, Scharp DW. Automated method for isolation of human pancreatic islets. Diabetes. 1988; 37(4):413. [PubMed: 3288530]

31. Shapiro AM, Ricordi C, Hering BJ, et al. International trial of the Edmonton protocol for islet transplantation. N Engl J Med. 2006; 355(13):1318. [PubMed: 17005949]

32. Froud T, Ricordi C, Baidal DA, et al. Islet transplantation in type 1 diabetes mellitus using cultured islets and steroid-free immunosuppression: Miami experience. Am J Transplant. 2005; 5(8):2037. [PubMed: 15996257]

33. Hering BJ, Kandaswamy R, Ansite JD, et al. Single-donor, marginal-dose islet transplantation in patients with type 1 diabetes. JAMA. 2005; 293(7):830. [PubMed: 15713772]

34. Alejandro R, Strasser S, Zucker PF, Mintz DH. Isolation of pancreatic islets from dogs. Semiautomated purification on albumin gradients. Transplantation. 1990; 50(2):207. [PubMed: 1696406]

35. Lake SP, Bassett PD, Larkins A, et al. Large-scale purification of human islets utilizing discontinuous albumin gradient on IBM 2991 cell separator. Diabetes. 1989; 38(Suppl 1):143. [PubMed: 2642839]

36. Linetsky E, Bottino R, Lehmann R, Alejandro R, Inverardi L, Ricordi C. Improved human islet isolation using a new enzyme blend, liberase. Diabetes. 1997; 46(7):1120. [PubMed: 9200645]

37. Kin T, Johnson PR, Shapiro AM, Lakey JR. Factors influencing the collagenase digestion phase of human islet isolation. Transplantation. 2007; 83(1):7. [PubMed: 17220782]

38. Johnson PR, White SA, London NJ. Collagenase and human islet isolation. Cell Transplant. 1996; 5(4):437. [PubMed: 8800512]

39. Brandhorst $\mathrm{H}$, Brandhorst $\mathrm{D}$, Hesse $\mathrm{F}$, et al. Successful human islet isolation utilizing recombinant collagenase. Diabetes. 2003; 52(5):1143. [PubMed: 12716744]

40. Brandhorst H, Brandhorst D, Hering BJ, Bretzel RG. Significant progress in porcine islet mass isolation utilizing liberase $\mathrm{HI}$ for enzymatic low-temperature pancreas digestion. Transplantation. 1999; 68(3):355. [PubMed: 10459538]

41. Bucher P, Mathe Z, Morel P, et al. Assessment of a novel two-component enzyme preparation for human islet isolation and transplantation. Transplantation. 2005; 79(1):91. [PubMed: 15714175] 
42. Barnett MJ, Zhai X, LeGatt DF, Cheng SB, Shapiro AM, Lakey JR. Quantitative assessment of collagenase blends for human islet isolation. Transplantation. 2005; 80(6):723. [PubMed: 16210957]

43. Yamamoto T, Ricordi C, Messinger S, et al. Deterioration and variability of highly purified collagenase blends used in clinical islet isolation. Transplantation. 2007; 84(8):997. [PubMed: 17989605]

44. Antonioli B, Fermo I, Cainarca S, et al. Characterization of collagenase blend enzymes for human islet transplantation. Transplantation. 2007; 84(12):1568. [PubMed: 18165766]

45. Kin T, Zhai X, Murdoch TB, Salam A, Shapiro AM, Lakey JR. Enhancing the success of human islet isolation through optimization and characterization of pancreas dissociation enzyme. Am J Transplant. 2007; 7(5):1233. [PubMed: 17359501]

46. Chadwick DR, Robertson GS, Toomey P, et al. Pancreatic islet purification using bovine serum albumin: the importance of density gradient temperature and osmolality. Cell Transplant. 1993; 2(4):355. [PubMed: 7512874]

47. Goto M, Eich TM, Felldin M, et al. Refinement of the automated method for human islet isolation and presentation of a closed system for in vitro islet culture. Transplantation. 2004; 78(9):1367. [PubMed: 15548977]

48. Markmann JF, Deng S, Huang X, et al. Insulin independence following isolated islet transplantation and single islet infusions. Ann Surg. 2003; 237(6):741. [PubMed: 12796569]

49. Ichii H, Pileggi A, Molano RD, et al. Rescue purification maximizes the use of human islet preparations for transplantation. Am J Transplant. 2005; 5(1):21. [PubMed: 15636608]

50. Matsumoto S, Noguchi H, Yonekawa Y, et al. Pancreatic islet transplantation for treating diabetes. Expert Opin Biol Ther. 2006; 6(1):23. [PubMed: 16370912]

51. Scharp DW, Lacy PE, Santiago JV, et al. Results of our first nine intraportal islet allografts in type 1, insulin-dependent diabetic patients. Transplantation. 1991; 51(1):76. [PubMed: 1987709]

52. Alejandro R, Feldman EC, Shienvold FL, Mintz DH. Advances in canine diabetes mellitus research: etiopathology and results of islet transplantation. J Am Vet Med Assoc. 1988; 193(9): 1050. [PubMed: 3143693]

53. Alejandro R, Cutfield RG, Shienvold FL, et al. Natural history of intrahepatic canine islet cell autografts. J Clin Invest. 1986; 78(5):1339. [PubMed: 3095376]

54. Warnock GL, Kneteman NM, Ryan EA, Rabinovitch A, Rajotte RV. Long-term follow-up after transplantation of insulin-producing pancreatic islets into patients with type 1 (insulin-dependent) diabetes mellitus. Diabetologia. 1992; 35(1):89. [PubMed: 1541386]

55. Goss JA, Schock AP, Brunicardi FC, et al. Achievement of insulin independence in three consecutive type-1 diabetic patients via pancreatic islet transplantation using islets isolated at a remote islet isolation center. Transplantation. 2002; 74(12):1761. [PubMed: 12499894]

56. Ryan EA, Paty BW, Senior PA, et al. Five-year follow-up after clinical islet transplantation. Diabetes. 2005; 54(7):2060. [PubMed: 15983207]

57. Warnock GL, Meloche RM, Thompson D, et al. Improved human pancreatic islet isolation for a prospective cohort study of islet transplantation vs best medical therapy in type 1 diabetes mellitus. Arch Surg. 2005; 140(8):735. [PubMed: 16103282]

58. Holmes MA, Clayton HA, Chadwick DR, Bell PR, London NJ, James RF. Functional studies of rat, porcine, and human pancreatic islets cultured in ten commercially available media. Transplantation. 1995; 60(8):854. [PubMed: 7482747]

59. Murdoch TB, McGhee-Wilson D, Shapiro AM, Lakey JR. Methods of human islet culture for transplantation. Cell Transplant. 2004; 13(6):605. [PubMed: 15648731]

60. Abdelli S, Ansite J, Roduit R, et al. Intracellular stress signaling pathways activated during human islet preparation and following acute cytokine exposure. Diabetes. 2004; 53(11):2815. [PubMed: 15504961]

61. Bottino R, Balamurugan AN, Tse H, et al. Response of human islets to isolation stress and the effect of antioxidant treatment. Diabetes. 2004; 53(10):2559. [PubMed: 15448084]

62. Matsuda T, Omori K, Vuong T, et al. Inhibition of p38 pathway suppresses human islet production of pro-inflammatory cytokines and improves islet graft function. Am J Transplant. 2005; 5(3):484. [PubMed: 15707402] 
63. Johansson H, Lukinius A, Moberg L, et al. Tissue factor produced by the endocrine cells of the islets of Langerhans is associated with a negative outcome of clinical islet transplantation. Diabetes. 2005; 54(6):1755. [PubMed: 15919797]

64. Moberg L, Johansson H, Lukinius A, et al. Production of tissue factor by pancreatic islet cells as a trigger of detrimental thrombotic reactions in clinical islet transplantation. Lancet. 2002; 360(9350):2039. [PubMed: 12504401]

65. Ichii H, Wang X, Messinger S, et al. Improved human islet isolation using nicotinamide. Am J Transplant. 2006; 6(9):2060. [PubMed: 16827790]

66. Marzorati S, Melzi R, Nano R, et al. In vitro modulation of monocyte chemoattractant protein-1 release in human pancreatic islets. Transplant Proc. 2004; 36(3):607. [PubMed: 15110609]

67. Piemonti L, Leone BE, Nano R, et al. Human pancreatic islets produce and secrete MCP-1/CCL2: relevance in human islet transplantation. Diabetes. 2002; 51(1):55. [PubMed: 11756323]

68. Bertuzzi F, Marzorati S, Maffi P, et al. Tissue factor and CCL2/monocyte chemoattractant protein-1 released by human islets affect islet engraftment in type 1 diabetic recipients. J Clin Endocrinol Metab. 2004; 89(11):5724. [PubMed: 15531535]

69. Chen MC, Proost P, Gysemans C, Mathieu C, Eizirik DL. Monocyte chemoattractant protein-1 is expressed in pancreatic islets from prediabetic NOD mice and in interleukin-1 beta-exposed human and rat islet cells. Diabetologia. 2001; 44(3):325. [PubMed: 11317664]

70. Moberg L, Olsson A, Berne C, et al. Nicotinamide inhibits tissue factor expression in isolated human pancreatic islets: implications for clinical islet transplantation. Transplantation. 2003; 76(9):1285. [PubMed: 14627904]

71. Goss JA, Goodpastor SE, Brunicardi FC, et al. Development of a human pancreatic islet-transplant program through a collaborative relationship with a remote islet-isolation center. Transplantation. 2004; 77(3):462. [PubMed: 14966428]

72. Kempf MC, Andres A, Morel P, et al. Logistics and transplant coordination activity in the GRAGIL Swiss-French multicenter network of islet transplantation. Transplantation. 2005; 79(9): 1200. [PubMed: 15880070]

73. Kessler L, Bucher P, Milliat-Guittard L, et al. Influence of islet transportation on pancreatic islet allotransplantation in type 1 diabetic patients within the Swiss-French GRAGIL network. Transplantation. 2004; 77(8):1301. [PubMed: 15114103]

74. Brunicardi FC. Clinical islet transplantation: a consortium model. Transplant Proc. 1996; 28(4): 2138. [PubMed: 8769181]

75. Brunicardi FC, Atiya A, Stock P, et al. Clinical islet transplantation experience of the University of California Islet Transplant Consortium. Surgery. 1995; 118(6):967. [PubMed: 7491541]

76. Rabkin JM, Olyaei AJ, Orloff SL, et al. Distant processing of pancreas islets for autotransplantation following total pancreatectomy. Am J Surg. 1999; 177(5):423. [PubMed: 10365884]

77. Pileggi A, Ricordi C, Kenyon NS, et al. Twenty years of clinical islet transplantation at the Diabetes Research Institute--University of Miami. Clin Transpl. 2004:177. [PubMed: 16704150]

78. Lee TC, Barshes NR, Brunicardi FC, et al. Procurement of the human pancreas for pancreatic islet transplantation. Transplantation. 2004; 78(3):481. [PubMed: 15316380]

79. Goss JA, Soltes G, Goodpastor SE, et al. Pancreatic islet transplantation: the radiographic approach. Transplantation. 2003; 76(1):199. [PubMed: 12865810]

80. Fraker CA, Alvarez S, Papadopoulos P, et al. Enhanced oxygenation promotes beta-cell differentiation in vitro. Stem Cells. 2007; 25(12):3155. [PubMed: 17761759]

81. Rozak PR, Weegman BP, Avgoustiniatos ES, et al. Devices and methods for maintenance of temperature and pressure during islet shipment. Transplant Proc. 2008; 40(2):407. [PubMed: 18374083]

82. Pileggi A, Alejandro R, Ricordi C. Clinical islet transplantation. Minerva Endocrinol. 2006; 31(3): 219. [PubMed: 17213789]

83. Ault A. Edmonton's islet success tough to duplicate elsewhere. Lancet. 2003; 361(9374):2054. [PubMed: 12814723] 
84. London NJ, Contractor H, Lake SP, Aucott GC, Bell PR, James RF. A microfluorometric viability assay for isolated human and rat islets of Langerhans. Diabetes Res. 1989; 12(3):141. [PubMed: 2699586]

85. Latif ZA, Noel J, Alejandro R. A simple method of staining fresh and cultured islets. Transplantation. 1988; 45(4):827. [PubMed: 2451869]

86. Ricordi C, Gray DW, Hering BJ, et al. Islet isolation assessment in man and large animals. Acta Diabetol Lat. 1990; 27(3):185. [PubMed: 2075782]

87. Ichii H, Inverardi L, Pileggi A, et al. A novel method for the assessment of cellular composition and beta-cell viability in human islet preparations. Am J Transplant. 2005; 5(7):1635. [PubMed: 15943621]

88. Fraker C, Timmins MR, Guarino RD, et al. The use of the BD oxygen biosensor system to assess isolated human islets of langerhans: oxygen consumption as a potential measure of islet potency. Cell Transplant. 2006; 15(8-9):745. [PubMed: 17269445]

89. Papas KK, Colton CK, Nelson RA, et al. Human islet oxygen consumption rate and DNA measurements predict diabetes reversal in nude mice. Am J Transplant. 2007; 7(3):707. [PubMed: 17229069]

90. Sweet IR, Gilbert M, Scott S, et al. Glucose-stimulated increment in oxygen consumption rate as a standardized test of human islet quality. Am J Transplant. 2008; 8(1):183. [PubMed: 18021279]

91. Goto M, Holgersson J, Kumagai-Braesch M, Korsgren O. The ADP/ATP ratio: A novel predictive assay for quality assessment of isolated pancreatic islets. Am J Transplant. 2006; 6(10):2483. [PubMed: 16869808]

92. Venturini M, Angeli E, Maffi P, et al. Technique, complications, and therapeutic efficacy of percutaneous transplantation of human pancreatic islet cells in type 1 diabetes: the role of US. Radiology. 2005; 234(2):617. [PubMed: 15591436]

93. Baidal DA, Froud T, Ferreira JV, Khan A, Alejandro R, Ricordi C. The bag method for islet cell infusion. Cell Transplant. 2003; 12(7):809. [PubMed: 14653627]

94. Froud T, Yrizarry JM, Alejandro R, Ricordi C. Use of D-STAT to prevent bleeding following percutaneous transhepatic intraportal islet transplantation. Cell Transplant. 2004; 13(1):55. [PubMed: 15040605]

95. Hafiz MM, Faradji RN, Froud T, et al. Immunosuppression and procedure-related complications in 26 patients with type 1 diabetes mellitus receiving allogeneic islet cell transplantation. Transplantation. 2005; 80(12):1718. [PubMed: 16378067]

96. Brennan DC, Shannon MB, Koch MJ, Polonsky KS, Desai N, Shapiro J. Portal vein thrombosis complicating islet transplantation in a recipient with the Factor V Leiden mutation. Transplantation. 2004; 78(1):172. [PubMed: 15257060]

97. Villiger P, Ryan EA, Owen R, et al. Prevention of bleeding after islet transplantation: lessons learned from a multivariate analysis of 132 cases at a single institution. Am J Transplant. 2005; 5(12):2992. [PubMed: 16303015]

98. Johansson H, Goto M, Dufrane D, et al. Low molecular weight dextran sulfate: a strong candidate drug to block IBMIR in clinical islet transplantation. Am J Transplant. 2006; 6(2):305. [PubMed: 16426314]

99. Cabric S, Sanchez J, Lundgren T, et al. Islet surface heparinization prevents the instant bloodmediated inflammatory reaction in islet transplantation. Diabetes. 2007; 56(8):2008. [PubMed: 17540953]

100. Ponte GM, Baidal DA, Romanelli P, et al. Resolution of severe atopic dermatitis after tacrolimus withdrawal. Cell Transplant. 2007; 16(1):23. [PubMed: 17436852]

101. Molinari M, Al-Saif F, Ryan EA, et al. Sirolimus-induced ulceration of the small bowel in islet transplant recipients: report of two cases. Am J Transplant. 2005; 5(11):2799. [PubMed: 16212644]

102. Kneteman NM, Lakey JR, Wagner T, Finegood D. The metabolic impact of rapamycin (sirolimus) in chronic canine islet graft recipients. Transplantation. 1996; 61(8):1206. [PubMed: 8610419] 
103. Fuhrer DK, Kobayashi M, Jiang H. Insulin release and suppression by tacrolimus, rapamycin and cyclosporin A are through regulation of the ATP-sensitive potassium channel. Diabetes Obes Metab. 2001; 3(6):393. [PubMed: 11903410]

104. Bell E, Cao X, Moibi JA, et al. Rapamycin has a deleterious effect on MIN-6 cells and rat and human islets. Diabetes. 2003; 52(11):2731. [PubMed: 14578291]

105. Zhang N, Su D, Qu S, et al. Sirolimus is associated with reduced islet engraftment and impaired beta-cell function. Diabetes. 2006; 55(9):2429. [PubMed: 16936190]

106. Marcelli-Tourvieille S, Hubert T, Moerman E, et al. In vivo and in vitro effect of sirolimus on insulin secretion. Transplantation. 2007; 83(5):532. [PubMed: 17353769]

107. Magliocca JF, Knechtle SJ. The evolving role of alemtuzumab (Campath-1H) for immunosuppressive therapy in organ transplantation. Transpl Int. 2006; 19(9):705. [PubMed: 16918530]

108. Liu C, Noorchashm H, Sutter JA, et al. B lymphocyte-directed immunotherapy promotes longterm islet allograft survival in nonhuman primates. Nat Med. 2007; 13(11):1295. [PubMed: 17965721]

109. O’Connell PJ, Hawthorne WJ, Holmes-Walker DJ, et al. Clinical islet transplantation in type 1 diabetes mellitus: results of Australia's first trial. Med J Aust. 2006; 184(5):221. [PubMed: 16515432]

110. Oberholzer J, Triponez F, Mage R, et al. Human islet transplantation: lessons from 13 autologous and 13 allogeneic transplantations. Transplantation. 2000; 69(6):1115. [PubMed: 10762216]

111. Lehmann R, Weber M, Berthold P, et al. Successful simultaneous islet-kidney transplantation using a steroid-free immunosuppression: two-year follow-up. Am J Transplant. 2004; 4(7):1117. [PubMed: 15196070]

112. Berney T, Buhler LH, Morel P. Pancreas allocation in the era of islet transplantation. Transpl Int. 2005; 18(7):763. [PubMed: 15948853]

113. Rickels MR, Schutta MH, Markmann JF, Barker CF, Naji A, Teff KL. \{beta\}-Cell function following human islet transplantation for type 1 diabetes. Diabetes. 2005; 54(1):100. [PubMed: 15616016]

114. Faradji RN, Monroy K, Messinger S, et al. Simple measures to monitor beta-cell mass and assess islet graft dysfunction. Am J Transplant. 2007; 7(2):303. [PubMed: 17173660]

115. Cardani R, Pileggi A, Ricordi C, et al. Allosensitization of islet allograft recipients. Transplantation. 2007; 84(11):1413. [PubMed: 18091517]

116. Campbell PM, Salam A, Ryan EA, et al. Pretransplant HLA antibodies are associated with reduced graft survival after clinical islet transplantation. Am J Transplant. 2007; 7(5):1242. [PubMed: 17456201]

117. Mohanakumar T, Narayanan K, Desai N, et al. A significant role for histocompatibility in human islet transplantation. Transplantation. 2006; 82(2):180. [PubMed: 16858280]

118. Shapiro AM, Ricordi C. Unraveling the secrets of single donor success in islet transplantation. Am J Transplant. 2004; 4(3):295. [PubMed: 14961980]

119. Rabkin JM, Leone JP, Sutherland DE, et al. Transcontinental shipping of pancreatic islets for autotransplantation after total pancreatectomy. Pancreas. 1997; 15(4):416. [PubMed: 9361097]

120. Poggioli R, Inverardi L, Ricordi C. Islet xenotransplantation. Cell Transplant. 2002; 11(2):89. [PubMed: 12099641]

121. Phelps CJ, Koike C, Vaught TD, et al. Production of alpha 1,3-galactosyltransferase-deficient pigs. Science. 2003; 299(5605):411. [PubMed: 12493821]

122. Bottino R, Balamurugan AN, Smetanka C, et al. Isolation outcome and functional characteristics of young and adult pig pancreatic islets for transplantation studies. Xenotransplantation. 2007; 14(1):74. [PubMed: 17214707]

123. Rood PP, Buhler LH, Bottino R, Trucco M, Cooper DK. Pig-to-nonhuman primate islet xenotransplantation: a review of current problems. Cell Transplant. 2006; 15(2):89. [PubMed: 16719044]

124. Diamond LE, Quinn CM, Martin MJ, Lawson J, Platt JL, Logan JS. A human CD46 transgenic pig model system for the study of discordant xenotransplantation. Transplantation. 2001; 71(1): 132. [PubMed: 11211178] 
125. Tseng YL, Moran K, Dor FJ, et al. Elicited antibodies in baboons exposed to tissues from alpha1,3-galactosyltransferase gene-knockout pigs. Transplantation. 2006; 81(7):1058. [PubMed: 16612284]

126. Cruise GM, Hegre OD, Lamberti FV, et al. In vitro and in vivo performance of porcine islets encapsulated in interfacially photopolymerized poly(ethylene glycol) diacrylate membranes. Cell Transplant. 1999; 8(3):293. [PubMed: 10442742]

127. Gazda LS, Adkins H, Bailie JA, et al. The use of pancreas biopsy scoring provides reliable porcine islet yields while encapsulation permits the determination of microbiological safety. Cell Transplant. 2005; 14(7):427. [PubMed: 16285251]

128. Safley SA, Kapp JA, Weber CJ. Proliferative and cytokine responses in CTLA4-Ig-treated diabetic NOD mice transplanted with microencapsulated neonatal porcine ICCs. Cell Transplant. 2002; 11(7):695. [PubMed: 12518896]

129. Sigrist S, Mechine-Neuville A, Mandes K, et al. Influence of VEGF on the viability of encapsulated pancreatic rat islets after transplantation in diabetic mice. Cell Transplant. 2003; 12(6):627. [PubMed: 14579931]

130. Hering BJ, Wijkstrom M, Graham ML, et al. Prolonged diabetes reversal after intraportal xenotransplantation of wild-type porcine islets in immunosuppressed nonhuman primates. Nat Med. 2006; 12(3):301. [PubMed: 16491083]

131. Cardona K, Korbutt GS, Milas Z, et al. Long-term survival of neonatal porcine islets in nonhuman primates by targeting costimulation pathways. Nat Med. 2006; 12(3):304. [PubMed: 16501570]

132. Soria B, Roche E, Berna G, Leon-Quinto T, Reig JA, Martin F. Insulin-secreting cells derived from embryonic stem cells normalize glycemia in streptozotocin-induced diabetic mice. Diabetes. 2000; 49(2):157. [PubMed: 10868930]

133. Lumelsky N, Blondel O, Laeng P, Velasco I, Ravin R, McKay R. Differentiation of embryonic stem cells to insulin-secreting structures similar to pancreatic islets. Science. 2001; 292(5520): 1389. [PubMed: 11326082]

134. Yang L, Li S, Hatch $\mathrm{H}$, et al. In vitro trans-differentiation of adult hepatic stem cells into pancreatic endocrine hormone-producing cells. Proc Natl Acad Sci U S A. 2002; 99(12):8078. [PubMed: 12048252]

135. Kodama S, Kuhtreiber W, Fujimura S, Dale EA, Faustman DL. Islet regeneration during the reversal of autoimmune diabetes in NOD mice. Science. 2003; 302(5648):1223. [PubMed: 14615542]

136. Ianus A, Holz GG, Theise ND, Hussain MA. In vivo derivation of glucose-competent pancreatic endocrine cells from bone marrow without evidence of cell fusion. J Clin Invest. 2003; 111(6): 843. [PubMed: 12639990]

137. De Coppi P, Bartsch G Jr, Siddiqui MM, et al. Isolation of amniotic stem cell lines with potential for therapy. Nat Biotechnol. 2007; 25(1):100. [PubMed: 17206138]

138. Bouwens L, Pipeleers DG. Extra-insular beta cells associated with ductules are frequent in adult human pancreas. Diabetologia. 1998; 41(6):629. [PubMed: 9662042]

139. Yatoh S, Dodge R, Akashi T, et al. Differentiation of affinity-purified human pancreatic duct cells to beta-cells. Diabetes. 2007; 56(7):1802. [PubMed: 17473224]

140. Ramiya VK, Maraist M, Arfors KE, Schatz DA, Peck AB, Cornelius JG. Reversal of insulindependent diabetes using islets generated in vitro from pancreatic stem cells. Nat Med. 2000; 6(3):278. [PubMed: 10700229]

141. Bonner-Weir S, Taneja M, Weir GC, et al. In vitro cultivation of human islets from expanded ductal tissue. Proc Natl Acad Sci U S A. 2000; 97(14):7999. [PubMed: 10884429]

142. Kroon E, Martinson LA, Kadoya K, et al. Pancreatic endoderm derived from human embryonic stem cells generates glucose-responsive insulin-secreting cells in vivo. Nat Biotechnol. 2008; 26(4):443. [PubMed: 18288110]

143. Ricordi C, Edlund H. Toward a renewable source of pancreatic beta-cells. Nat Biotechnol. 2008; 26(4):397. [PubMed: 18392020]

144. Calne R, Moffatt SD, Friend PJ, et al. Campath IH allows low-dose cyclosporine monotherapy in 31 cadaveric renal allograft recipients. Transplantation. 1999; 68(10):1613. [PubMed: 10589966] 
145. Knechtle SJ, Pirsch JD, H Fechner J J, et al. Campath-1H induction plus rapamycin monotherapy for renal transplantation: results of a pilot study. Am J Transplant. 2003; 3(6):722. [PubMed: 12780564]

146. Rao V, Pirsch JD, Becker BN, Knechtle SJ. Sirolimus monotherapy following Campath-1H induction. Transplant Proc. 2003; 35(3 Suppl):128S. [PubMed: 12742484]

147. Kenyon NS, Chatzipetrou M, Masetti M, et al. Long-term survival and function of intrahepatic islet allografts in rhesus monkeys treated with humanized anti-CD154. Proc Natl Acad Sci U S A. 1999; 96(14):8132. [PubMed: 10393960]

148. Kenyon NS, Fernandez LA, Lehmann R, et al. Long-term survival and function of intrahepatic islet allografts in baboons treated with humanized anti-CD154. Diabetes. 1999; 48(7):1473. [PubMed: 10389857]

149. Larsen CP, Pearson TC, Adams AB, et al. Rational development of LEA29Y (belatacept), a highaffinity variant of CTLA4-Ig with potent immunosuppressive properties. Am J Transplant. 2005; 5(3):443. [PubMed: 15707398]

150. Vincenti F, Larsen C, Durrbach A, et al. Costimulation blockade with belatacept in renal transplantation. N Engl J Med. 2005; 353(8):770. [PubMed: 16120857]

151. Kawai T, Cosimi AB, Spitzer TR, et al. HLA-mismatched renal transplantation without maintenance immunosuppression. N Engl J Med. 2008; 358(4):353. [PubMed: 18216355]

152. Yasunami Y, Lacy PE, Finke EH. A new site for islet transplantation--a peritoneal-omental pouch. Transplantation. 1983; 36(2):181. [PubMed: 6410557]

153. Rajotte RV, Tighe VM, Warnock GL, Kneteman NM, Finegood DT. New site for islet transplantation in rats--liver-mesentery or liver-omental pouch. Transplant Proc. 1994; 26(2):675. [PubMed: 8171606]

154. Chaffanjon PC, Kenyon NM, Ricordi C, Kenyon NS. Omental anatomy of non-human primates. Surg Radiol Anat. 2005; 27(4):287. [PubMed: 16237487]

155. Kobayashi T, Aomatsu Y, Iwata H, et al. Survival of microencapsulated islets at 400 days posttransplantation in the omental pouch of NOD mice. Cell Transplant. 2006; 15(4):359. [PubMed: 16898230]

156. Rafael E, Tibell A, Ryden M, et al. Intramuscular autotransplantation of pancreatic islets in a 7year-old child: a 2-year follow-up. Am J Transplant. 2008; 8(2):458. [PubMed: 18093267]

157. Pileggi A, Molano RD, Ricordi C, et al. Reversal of diabetes by pancreatic islet transplantation into a subcutaneous, neovascularized device. Transplantation. 2006; 81(9):1318. [PubMed: 16699461]

158. Juang JH, Bonner-Weir S, Ogawa Y, Vacanti JP, Weir GC. Outcome of subcutaneous islet transplantation improved by polymer device. Transplantation. 1996; 61(11):1557. [PubMed: 8669096]

159. Kawakami $\mathrm{Y}$, Iwata $\mathrm{H}, \mathrm{Gu} \mathrm{Y}$, et al. Modified subcutaneous tissue with neovascularization is useful as the site for pancreatic islet transplantation. Cell Transplant. 2000; 9(5):729. [PubMed: 11144974]

160. Gu Y, Tabata Y, Kawakami Y, et al. Development of a new method to induce angiogenesis at subcutaneous site of streptozotocin-induced diabetic rats for islet transplantation. Cell Transplant. 2001; 10(4-5):453. [PubMed: 11549071]

161. Kawakami Y, Iwata H, Gu YJ, et al. Successful subcutaneous pancreatic islet transplantation using an angiogenic growth factor-releasing device. Pancreas. 2001; 23(4):375. [PubMed: 11668206] 